\title{
SYNTHESIS, CHARACTERIZATION AND BIOLOGICAL ACTIVITY OF MIXED LIGAND (IMINE OF BENZIDINE AND 1,10-PHENANTHROLINE) COMPLEXES WITH Fe(II), Co(II), Ni(II) AND Cu(II) IONS
}

\author{
Zainab M. Hassan', Rawaa A. Alattar', Suhad Kareem Abass', \\ Hayder Hamied Mihsen ${ }^{1} \bowtie$, Zainab Fadhil Abbas ${ }^{2}$, Khalid A. Hussain ${ }^{2}$
}

https://doi.org/10.23939/chcht16.01.015

\begin{abstract}
In this paper, binuclear metal complexes of the metal ions $\mathrm{Fe}(\mathrm{II}), \mathrm{Co}(\mathrm{II}), \mathrm{Ni}(\mathrm{II})$ and $\mathrm{Cu}(\mathrm{II})$ were synthesized by the reaction of the primary ligand (imine of benzidine) $\left(\mathrm{H}_{2} \mathrm{~L}\right)$ and the secondary ligand $(1,10$ phenanthroline) ( $\left.\mathrm{L}^{\prime}\right)$ with these metal ions in a molar ratio of 1:2:2, respectively. The complexes were characterized using CHN elemental analysis, FT-IR, UV-Vis, magnetic susceptibility, molar conductivity, ${ }^{1} \mathrm{H}$ NMR, and TGADTA thermogravimetric analysis. According to the results obtained from the elemental analysis and spectral measurements where complexes of $\mathrm{Fe}(\mathrm{II}), \mathrm{Co}(\mathrm{II})$ and $\mathrm{Ni}(\mathrm{II})$ have octahedral geometry, while the complex with $\mathrm{Cu}(\mathrm{II})$ has a square planar geometry. All the prepared complexes are wholly stable and can keep for months without any significant change. The antibacterial activities of the prepared compounds were evaluated with regard to two bacteria species, gram-negative Proteus and Kelbsiella, by using diffusion agar plates. The inhibition zone diameter around the holes indicated the sensitivity of the bacteria to these compounds, where the Klebsiella bacteria were revealed to be more highly sensitive to these compounds than Proteus bacteria. All synthesized complexes showed more significant effects against Kelbsiella and Protea than the antibiotic (Amikacin).
\end{abstract}

Keywords: Schiff base, binuclear metal complexes, 1,10phenanthroline, thermogravimetric analysis, biological activities.

\footnotetext{
${ }^{1}$ Department of Chemistry, College of Science, University of Kerbala, Karbala, Iraq

${ }^{2}$ Department of Biology, College of Science, University of Kerbala, Karbala, Iraq

\hayderalhmedat@gmail.com; hayderalhmedawy@gmail.com (C) Hassan, Z.M.; Alattar, R.A.; Abass, S.K.; Mihsen H.H.; Abbas, Z.F.; Hussain. K.A., 2022
}

\section{Introduction}

Imine compounds containing the azomethine $(\mathrm{C}=\mathrm{N})$ group are considered good coordinating ligands when they bear a functional group such as the hydroxyl, amine or thiol due to the formation of a five- or six-membered chelate with a metal ion. ${ }^{1,2}$ Imine compounds and their transition metal complexes have attracted considerable interest due to their antibacterial, ${ }^{3}$ antifungal, ${ }^{4}$ antiviral, ${ }^{5}$ antimalarial, ${ }^{6}$ anticancer, $^{7}$ and antitumour ${ }^{8}$ activities. Benzidine compounds form a variety of Schiff bases with aldehydes/ ketones and are reported to be superior reagents in biological, pharmacological, clinical and analytical applications which are improved by complexation with transition metal ions. ${ }^{9-11}$ Heterocyclic compound such as 1,10-phenanthroline (Phen) is a good ligand due to the presence of two-ring nitrogen atom with a localized pair of electrons. ${ }^{12}$ A large number of mixed-ligand complexes involving 1,10-phenanthroline has been prepared by different researchers ${ }^{12,13}$ due to their biological applications, structural properties and activity as corrosion inhibitors.

In this work, we synthesized a number of complexes with an imine ligand $\left(\mathrm{H}_{2} \mathrm{~L}\right)$ derived from salicylaldehyde and benzidine as the primary ligand and 1,10-phenanthroline (L') as a co-ligand, and the metal ions $\mathrm{Fe}(\mathrm{II}), \mathrm{Co}(\mathrm{II}), \mathrm{Ni}(\mathrm{II})$ and $\mathrm{Cu}(\mathrm{II})$ in a molar ratio of 1:2:2, respectively. We also estimated the antimicrobial activities of prepared complexes against Proteus and Kelbsiella bacteria.

\section{Experimental}

\subsection{Materials and Reagents}

All the chemicals and solvents for the prepared compound were of analytical grade. The methanol, 
ethanol, glacial acetic acid, DMF, DMSO and other solvents used were of high purity and supplied by BDH. Benzidine, salicylaldehyde, 1,10-phenanthroline and metals salts $\left(\mathrm{FeCl}_{2} \cdot 6 \mathrm{H}_{2} \mathrm{O}, \mathrm{CoCl}_{2} \cdot 6 \mathrm{H}_{2} \mathrm{O}, \mathrm{NiCl}_{2} \cdot 6 \mathrm{H}_{2} \mathrm{O}\right.$ and $\mathrm{CuCl}_{2} \cdot 2 \mathrm{H}_{2} \mathrm{O}$ ), were supplied by BDH and Sigma-Aldrich. $\mathrm{CHN}$ elemental analysis was undertaken for the ligand and complexes using an Euro EA Elemental Analyzer. Infrared spectra for the ligand and complexes were recorded via a Fourier transform-infrared (FT-IR) spectrometer using a $\mathrm{KBr}$ disk in the frequency range of $4000-400 \mathrm{~cm}^{-1}$ using a Shimadzu Corporation $8000 \mathrm{~S}$ FTIR spectrometer. All electronic spectra of the prepared compounds have been recorded in the region of 200$1100 \mathrm{~nm}$ using a Shimadzu UV-240 UV-visible recorder spectrometer using dimethylformamide (DMF) as a solvent at the concentration of $1 \cdot 10^{-3} \mathrm{M}$. Magnetic susceptibilities obtained for the complexes were found at room temperature using a Magnetic Susceptibility Balance-MSBMKI. Molar conductivity was measured using a Jenway Ltd-4071 Digital conductivity meter using DMF as a solvent at the concentration of $1 \cdot 10^{-3} \mathrm{M}$. Melting points were measured using a Stuart melting point apparatus.

\subsection{Synthesis of Primary Ligand $\left(\mathrm{H}_{2} \mathrm{~L}\right)(9)$}

The ligand $\left(\mathrm{H}_{2} \mathrm{~L}\right)$ was prepared from the reaction of $0.032 \mathrm{~mol}$ salicylaldehyde with $0.016 \mathrm{~mol}$ benzidine in $25 \mathrm{~mL}$ absolute ethanol and 1-2 drops of glacial acetic acid, which was then refluxed at $343 \mathrm{~K}$ in a water bath for $2-3 \mathrm{~h}$. The product which was separated out on subsequent cooling was filtered off. A yellow precipitate was obtained and then recrystallized from a hot mixture of $5 \mathrm{~mL}$ ethanol, $2 \mathrm{~mL}$ distilled water and $5 \mathrm{~mL}$ acetone. The product yield was almost $75 \%$, and a melting point was $491 \mathrm{~K}$. The synthesis of the ligand is shown in Scheme 1.

\subsection{Synthesis of the Binuclear Complexes}

$0.392 \mathrm{~g}(1 \mathrm{mmol})$ of $\mathrm{H}_{2} \mathrm{~L}$ ligand was added to the ethanolic solution of potassium hydroxide and $0.364 \mathrm{~g}$ ( $2 \mathrm{mmol}$ ) of 1,10-phenanthroline(phen) in a $100 \mathrm{~mL}$ roundbottomed flask. The appropriate amount of ethanolic solution of each metal salt, namely $\left[\mathrm{FeCl}_{2} \cdot 6 \mathrm{H}_{2} \mathrm{O}\right]$, $\left[\mathrm{NiCl}_{2} \cdot 6 \mathrm{H}_{2} \mathrm{O}\right],\left[\mathrm{CoCl}_{2} \cdot 6 \mathrm{H}_{2} \mathrm{O}\right]$ and $\left[\mathrm{CuCl}_{2} \cdot 2 \mathrm{H}_{2} \mathrm{O}\right]$ was added in a ratio of 1:2:2 for $\mathrm{H}_{2} \mathrm{~L}: 1,10$-phenanthroline:metal salt. The reaction mixture was refluxed for about $3 \mathrm{~h}$ at $328 \mathrm{~K}$. The resulting product was filtered and washed using a hot ethanol and finally dried for $24 \mathrm{~h}$. The synthesis of the complexes is shown in Scheme 2.
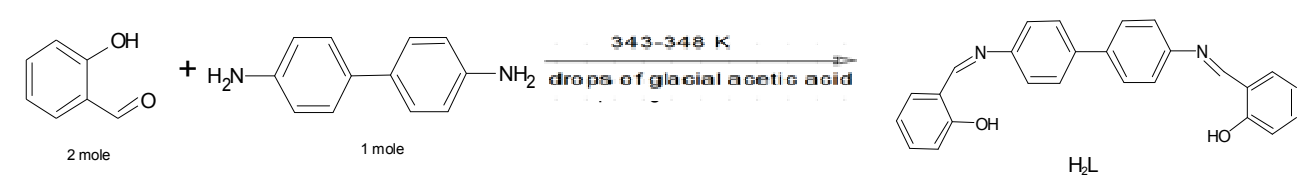

Scheme 1. Synthetic route for the preparation of ligand $\left(\mathrm{H}_{2} \mathrm{~L}\right)$
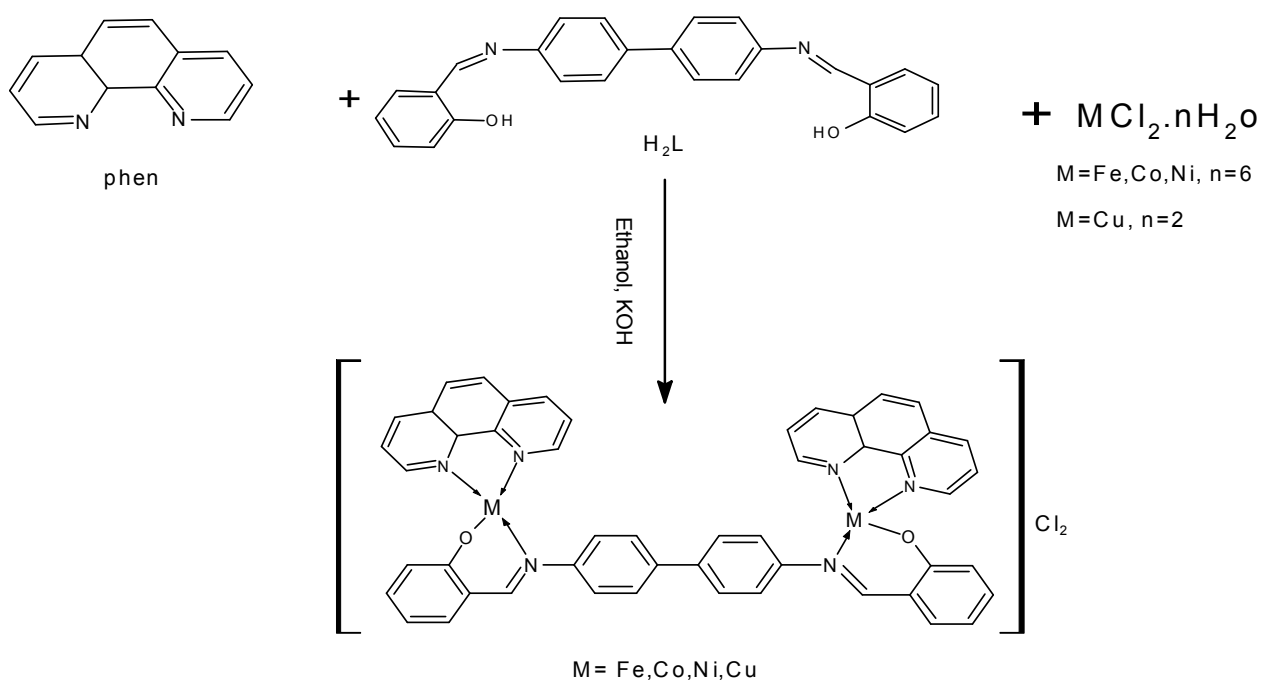

Scheme 2. General reaction for synthesis of prepared complexes 


\subsection{Antibacterial Activity}

In this study, the antibacterial activity of the $\left(\mathrm{H}_{2} \mathrm{~L}\right)$ ligand and its prepared complexes was tested in DMSO as a solvent against the growth of two pathogenic microbes (Proteus sp. and Klebseilla sp.) which are representative of gram-negative bacteria, which were obtained and identified from the laboratories of the Biology Department, College of Science, University of Kerbala, Iraq. The microbes isolated were first activated by the development of bacteria in a nutrient broth medium, ${ }^{14}$ after which the well diffusion assay method was used to determine the antibacterial activity of the prepared compounds.

To determine the antibacterial activity of the complexes against the studied bacteria we prepared a stock of the young bacteria (at an age of $24 \mathrm{~h}$ ) by transferring a colony to a physiological saline solution and controlling its turbidity with the first tube of a standard McFarland tube then spreading it onto Muller Hinton Agar and leaving the dishes for $15 \mathrm{~min}$ to infuse the medium with a bacterial legation. A hole was placed in the centre of each dish using a sterile corky borer induplicate rate for each compound, then $100 \mu 1$ of the prepared solutions were added to these holes using a micropipette, and which were then placed in the incubator at $310 \mathrm{~K}$ for $24 \mathrm{~h}$. The inhibition zone was then measured around each hole, ${ }^{15}$ and compared with Amikacin $(10 \mathrm{mg}$ disc) following the standard method of Bauer et al. ${ }^{16}$

\section{Results and Discussion}

The binuclear complexes prepared by reaction of $\mathrm{H}_{2} \mathrm{~L}$ with 1,10-phenanthroline and the metal salts were added in the ratio 1:2:2 $\left(\mathrm{H}_{2} \mathrm{~L}: 1,10\right.$-phenanthroline:metal salt). The complexes were characterized by means of elemental analysis, infrared and UV-Vis spectra, ${ }^{1} \mathrm{H}$ NMR, magnetic susceptibility and thermal analysis.

\subsection{Physical Properties and Elemental Analysis of the Ligand and its Complexes}

The physical properties and $\mathrm{CHN}$ element analysis are reported in Table 1, where the latter for the ligand and its compounds almost correspond to the theoretical results calculated for the suggested formulae. Physical features (melting point (MP) and colour) for $\mathrm{H}_{2} \mathrm{~L}$ and its complexes can be seen, which show that the colour of the ligand differs from the colours of the synthesised complexes, and the high melting points indicate high photostability and stability in air.

\subsection{IR Spectroscopic Investigations}

The IR absorption spectra of the Schiff base for the ligand $\left(\mathrm{H}_{2} \mathrm{~L}\right)$, as shown in Fig. 1, showed the absence of absorption bands for stretching vibrations (symmetrical and asymmetrical) of the secondary amine $\mathrm{NH}_{2}$ of benzidine and the stretching vibration of the carbonyl group $(\mathrm{C}=\mathrm{O})$ of salicylaldehyde, and the appearance of a stretching vibration for the azomethine group $(-\mathrm{C}=\mathrm{N})$ at $1610 \mathrm{~cm}^{-1}$ and a broad band at $3465 \mathrm{~cm}^{-1}$, which belong to hydroxyl group. ${ }^{17}$ The stretching frequency of the hydroxyl group $v(\mathrm{O}-\mathrm{H})$ is absent in the IR spectra of all prepared complexes (see Fig. 1), which confirms coordination via the hydroxyl oxygen atom. It was also observed that all the absorption bands associated with the azomethine group $(\mathrm{C}=\mathrm{N})$ for the Schiff base and 1,10phenanthroline appeared in the same region and were shifted to lower and higher frequencies due to coordination with metal ions via the nitrogen atom. The new bands appeared in the regions of 536-623 and 445$538 \mathrm{~cm}^{-1}$ likely due to the formation of $\mathrm{M}-\mathrm{O}$ and $\mathrm{M}-\mathrm{N}$ bonds, respectively. ${ }^{5,18-20}$

Table 1. Physical properties and elemental analysis for the ligand $\left(\mathrm{H}_{2} \mathrm{~L}\right)$ and its complexes

\begin{tabular}{|c|c|c|c|c|c|c|c|}
\hline \multirow[t]{2}{*}{ Compound } & \multirow[t]{2}{*}{$\begin{array}{c}\text { Molecular } \\
\text { weight, } \mathrm{g} / \mathrm{mol}\end{array}$} & \multicolumn{3}{|c|}{$\begin{array}{c}\text { Elemental analysis, \% } \\
\left(\frac{\text { Found }}{\text { Calcd. })}\right.\end{array}$} & \multirow[t]{2}{*}{ Color } & \multirow[t]{2}{*}{ MP, K } & \multirow[t]{2}{*}{ Yield, \% } \\
\hline & & $\mathrm{C}$ & $\mathrm{H}$ & $\mathrm{N}$ & & & \\
\hline $\mathrm{H}_{2} \mathrm{~L}$ & 392.46 & $\begin{array}{c}79.25 \\
(79.57)\end{array}$ & $\begin{array}{c}5.14 \\
(4.89)\end{array}$ & $\begin{array}{c}7.14 \\
(6.95)\end{array}$ & Bright yellow & 482 & 80 \\
\hline$\left[\mathrm{Co}_{2}\left(\mathrm{H}_{2} \mathrm{~L}\right)\left(\mathrm{L}^{\prime}\right)_{2}\right] \mathrm{Cl}_{2}$ & 939.63 & $\begin{array}{c}63.91 \\
(63.29)\end{array}$ & $\begin{array}{c}3.65 \\
(2.99)\end{array}$ & $\begin{array}{c}8.94 \\
(8.46)\end{array}$ & Brownish orange & 296 & 74 \\
\hline$\left[\mathrm{Cu}_{2}\left(\mathrm{H}_{2} \mathrm{~L}\right)\left(\mathrm{L}^{\prime}\right)_{2}\right] \mathrm{Cl}_{2}$ & 948.85 & $\begin{array}{c}63.29 \\
(63.56)\end{array}$ & $\begin{array}{c}3.61 \\
(3.13)\end{array}$ & $\begin{array}{c}8.86 \\
(8.42)\end{array}$ & Brown & 569 & 68 \\
\hline$\left[\mathrm{Ni}_{2}\left(\mathrm{H}_{2} \mathrm{~L}\right)\left(\mathrm{L}^{\prime}\right)_{2}\right] \mathrm{Cl}_{2}$ & 939.15 & $\begin{array}{c}63.95 \\
(64.22) \\
\end{array}$ & $\begin{array}{c}3.65 \\
(3.53) \\
\end{array}$ & $\begin{array}{c}8.95 \\
(8.32) \\
\end{array}$ & Greenish yellow & 515 & 75 \\
\hline$\left[\mathrm{Fe}_{2}\left(\mathrm{H}_{2} \mathrm{~L}\right)\left(\mathrm{L}^{\prime}\right)_{2}\right] \mathrm{Cl}_{2}$ & 933.45 & $\begin{array}{c}64.34 \\
(64.01)\end{array}$ & $\begin{array}{c}3.67 \\
(3.23)\end{array}$ & $\begin{array}{c}9.00 \\
(8.89)\end{array}$ & Dark brown & 507 & 65 \\
\hline
\end{tabular}


Table 2. Some IR data for $\mathrm{H}_{2} \mathrm{~L}$ and its complexes $\left(\mathrm{cm}^{-1}\right)$

\begin{tabular}{|c|c|c|c|c|c|}
\hline Compounds & $v(\mathrm{C}-\mathrm{H})$ aliphatic & $v(\mathrm{C}-\mathrm{H})$ aromatic & $v(\mathrm{C}=\mathrm{N})$ & $v(\mathrm{M}-\mathrm{N})$ & $v(\mathrm{M}-\mathrm{O})$ \\
\hline $\mathrm{H}_{2} \mathrm{~L}$ & 2984.76 & 3053.42 & 1610.61 & - & - \\
\hline$\left[\mathrm{Co}_{2}\left(\mathrm{H}_{2} \mathrm{~L}_{2}\left(\mathrm{~L}^{\prime}\right)\right] \mathrm{Cl}_{2}\right.$ & 2989.76 & 3053.42 & 1618.33 & 551.66 & 443.64 \\
\hline$\left[\mathrm{Fe}_{2}\left(\mathrm{H}_{2} \mathrm{~L}\right)_{2}\left(\mathrm{~L}^{\prime}\right)\right] \mathrm{Cl}_{2}$ & 2989.76 & 3051.49 & 1618.33 & 549.73 & 443.64 \\
\hline$\left[\mathrm{Ni}_{2}\left(\mathrm{H}_{2} \mathrm{~L}\right)_{2}\left(\mathrm{~L}^{\prime}\right)\right] \mathrm{Cl}_{2}$ & 3055.35 & 3363.97 & 1620.26 & 549.10 & 443.64 \\
\hline$\left[\mathrm{Cu}_{2}\left(\mathrm{H}_{2} \mathrm{~L}\right)_{2}\left(\mathrm{~L}^{\prime}\right)\right] \mathrm{Cl}_{2}$ & 3051.49 & 3390.34 & 1608.69 & 540.09 & 445.57 \\
\hline
\end{tabular}

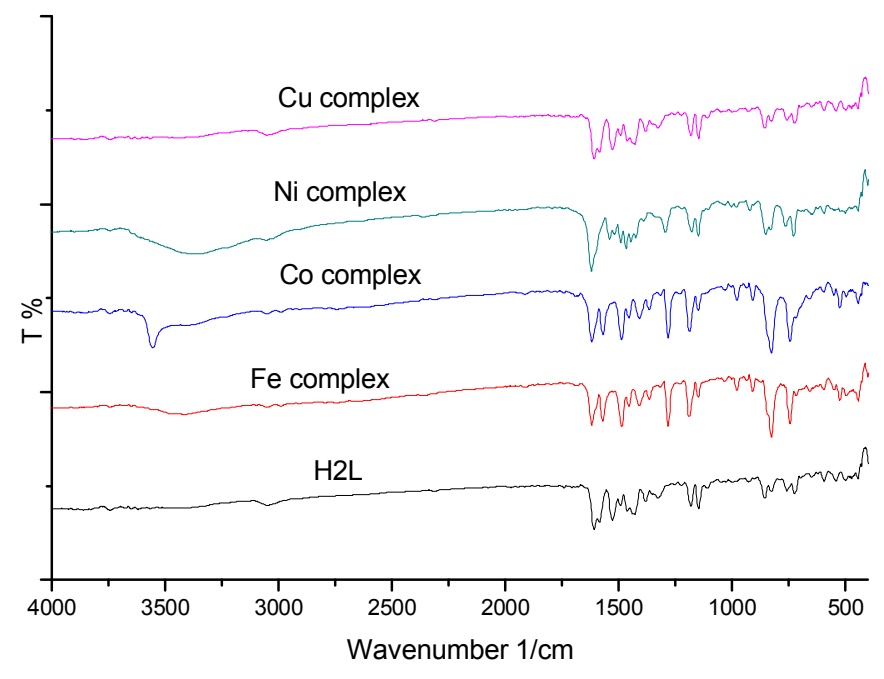

Fig. 1. IR spectra of $\mathrm{H}_{2} \mathrm{~L}$ and its complexes

\subsection{Electronic Spectra, Molar Conductivity, and Magnetic Susceptibility}

The electronic spectrum of the, $\mathrm{H}_{2} \mathrm{~L}$ ligand, as shown in Fig. 2, displayed two absorption bands, with the first at $222 \mathrm{~nm}$ belonged to the $\left(\pi-\pi^{*}\right)$ transition and the second band at $356 \mathrm{~nm}$ belonged to the $\left(\mathrm{n}-\pi^{*}\right)$ transition. $^{21}$ The electronic spectrum of the $\left[\mathrm{Fe}_{2}\left(\mathrm{H}_{2} \mathrm{~L}\right)_{2}\left(\mathrm{~L}^{\prime}\right)\right] \mathrm{Cl}_{2}$ complex, as shown in Fig. 3, exhibits two peaks, the first intense peak at $246 \mathrm{~nm}$ being due to the ligand field transitions, and the second broad band at $371 \mathrm{~nm}$ being due to the charge transition. ${ }^{22}$ The conductivity of the $\left[\mathrm{Fe}_{2}\left(\mathrm{H}_{2} \mathrm{~L}\right)_{2}\left(\mathrm{~L}^{\prime}\right)\right] \mathrm{Cl}_{2}$ complex was $135.3 \mu \mathrm{S} / \mathrm{cm}$, which indicates a conductivity of $1: 2$, while the magnetic moment for this complex was 5.25 B.M,which indicates four single electrons in a tetrahedral environment. ${ }^{23}$ The electronic spectrum of the $\left[\mathrm{Co}_{2}\left(\mathrm{H}_{2} \mathrm{~L}\right)_{2}\left(\mathrm{~L}^{\prime}\right)\right] \mathrm{Cl}_{2}$ complex (Fig. 4) showed a broad, low-intensity band at $256 \mathrm{~nm}$ which is due to the ligand field transitions, and a second high-intensity band at $370 \mathrm{~nm}$ which is due to the charge transition. The magnetic susceptibility (5.04 B.M) and molar conductivity $(161.5 \mu \mathrm{S} / \mathrm{cm})$ measurements indicated that the complex is paramagnetic and electrolytic (ratio 1:2), which indicates a tetrahedral geo- metry around the $\mathrm{Co}(\mathrm{II})$ ion. ${ }^{24}$ The electronic spectrum of the $\left[\mathrm{Ni}_{2}\left(\mathrm{H}_{2} \mathrm{~L}\right)\left(\mathrm{L}^{\prime}\right)_{2}\right] \mathrm{Cl}_{2}$ complex (Fig. 5) showed two bands at 250 and $269 \mathrm{~nm}$, corresponding to a ligand field transition, while a charge transfer band appeared at $371 \mathrm{~nm}$ and a d-d transition band at $693 \mathrm{~nm}$ belonging to $\left.\mathrm{U}_{2}:{ }^{3} \mathrm{~T}_{1(\mathrm{~F})} \rightarrow{ }^{3} \mathrm{~T}_{2}\right)$ in the tetrahedral geometry of $\mathrm{Ni}(\mathrm{II})$ complexes. $^{22}$ The magnetic susceptibility was 3.75 B.M and the molar conductivity measurement in DMF was $156 \mu \mathrm{S} / \mathrm{cm}$ in type $1: 2$, which indicated that the complex is paramagnetic and electrolytic. From these results, tetrahedral geometry around $\mathrm{Ni}(\mathrm{II})$ can be suggested. ${ }^{22,25}$ The spectrum of the $\left[\mathrm{Cu}_{2}\left(\mathrm{H}_{2} \mathrm{~L}\right)_{2}\left(\mathrm{~L}^{\prime}\right)\right] \mathrm{Cl}_{2}$ complex (Fig. 6) exhibited two peaks. The first high-intensity peak at $249 \mathrm{~nm}$ was due to the ligand field transition, while the second broad band at $370 \mathrm{~nm}$ was due to the charge transfer transition. These transitions indicate a square planar geometry around the $\mathrm{Cu}$ (II) ion. $^{20}$ The $\mathrm{Cu}$ (II) complex shows a value of $\mu_{\text {eff }}=1.73 \mu \mathrm{V}$. The observed magnetic moments of $\mathrm{Cu}$ (II) show one unpaired electron with a paramagnetic kind and propose a square planer geometry in terms of Jahn-Teller effect. The molar conductivity measurement was $168 \mu \mathrm{S} / \mathrm{cm}$, indicating that the complex was the electrolytic one. According to these data, a square planar geometry around the $\mathrm{Cu}(\mathrm{II})$ ion can be suggested. ${ }^{26}$ 


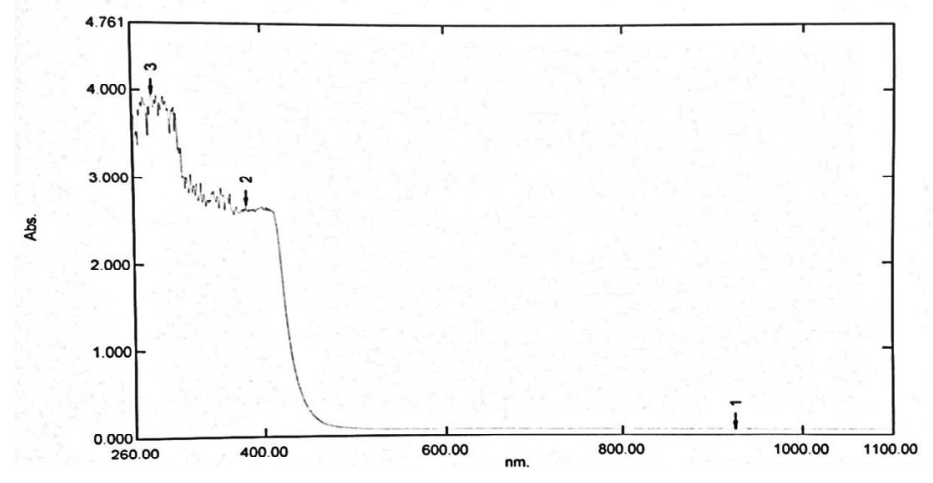

Fig. 2. UV-Vis spectrum for $\mathrm{H}_{2} \mathrm{~L}$ ligand

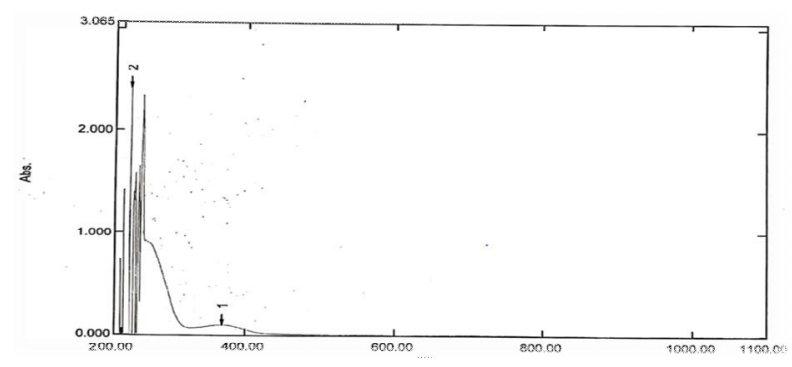

Fig. 3. $\mathrm{UV}-\mathrm{V}$ is spectrum for $\left[\mathrm{Fe}_{2}\left(\mathrm{H}_{2} \mathrm{~L}\right)\left(\mathrm{L}^{\prime}\right)_{2}\right] \mathrm{Cl}_{2}$

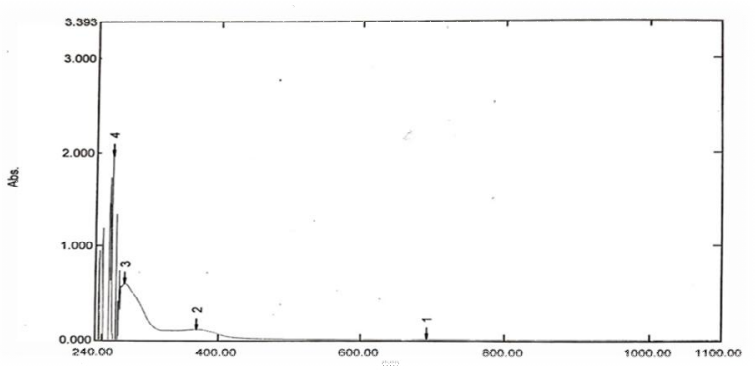

Fig. 5. UV-Vis spectrum for $\left[\mathrm{Ni}_{2}\left(\mathrm{H}_{2} \mathrm{~L}\right)\left(\mathrm{L}^{\prime}\right)_{2}\right] \mathrm{Cl}_{2}$

\section{4. ${ }^{1}$ HNMR Spectra}

The ${ }^{1}$ HNMR spectra (Figs.7-12) were recorded for the Schiff base ligand $\left(\mathrm{H}_{2} \mathrm{~L}\right)$ and its metal complexes in DMSO as the solvent and showed the following chemical shifts; multiple signal chemical shifts between 6.97$7.89 \mathrm{ppm}$ belong to the protons in aromatic rings, the singlet chemical shift at 9.01-9.10 ppm is attributed to the proton attached to $\mathrm{C}=\mathrm{N}$ group. ${ }^{27}$ The ${ }^{1} \mathrm{H}$ NMR spectrum of the ligand $\left(\mathrm{H}_{2} \mathrm{~L}\right)$ showed the hydroxyl protons appeared at $\delta=13.27 \mathrm{ppm}$. The chemical shifts of the hydroxyl disappeared in all complexes, while those of the $\mathrm{C}=\mathrm{N}$ group shifted due to coordination with the metal ion.

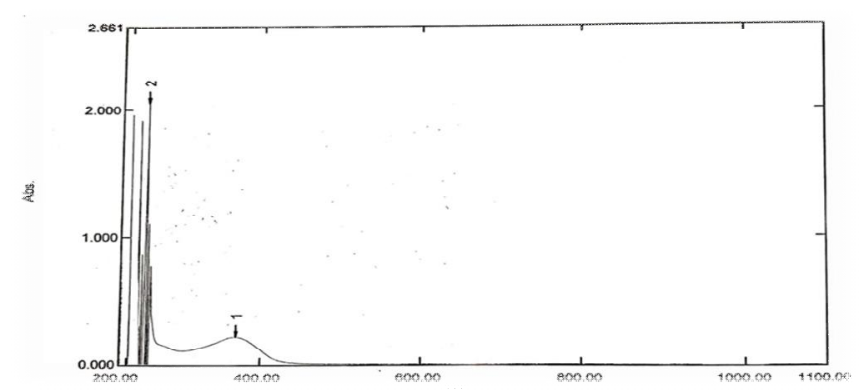

Fig. 4. $\mathrm{UV}-\mathrm{V}$ is spectrum for $\left[\mathrm{Co}_{2}\left(\mathrm{H}_{2} \mathrm{~L}\right)\left(\mathrm{L}^{\prime}\right)_{2}\right] \mathrm{Cl}_{2}$

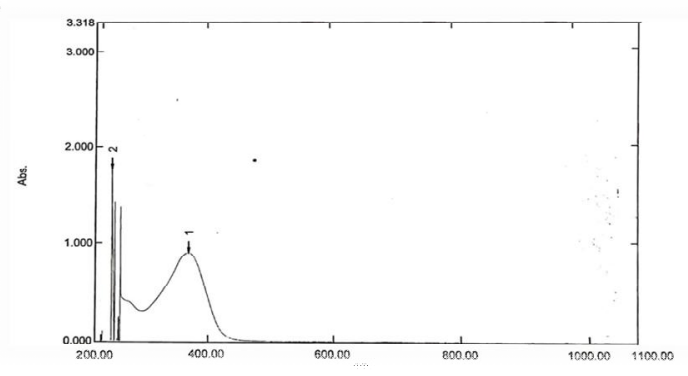

Fig. 6. $\mathrm{UV}-\mathrm{V}$ is spectrum for $\left[\mathrm{Cu}_{2}\left(\mathrm{H}_{2} \mathrm{~L}\right)\left(\mathrm{L}^{\prime}\right)_{2}\right] \mathrm{Cl}_{2}$

\subsection{Thermogravimetric Analyses (TGA/DTA)}

Table 3 and Figs. 13-17 show the thermal decomposition steps of the ligand $\mathrm{H}_{2} \mathrm{~L}$ and their metal complexes via the TGA and DTA techniques within the range of $303-1173 \mathrm{~K}$ at a heating rate of $20 \mathrm{~K} / \mathrm{min}$ under a nitrogen atmosphere. Found and calculated weight loss, thermal range, decomposed compounds and produced compounds are shown in Table 3. Ionic chlorine molecules that were not directly coordinated to the metal ion were found to be lost at lower temperatures. The stages of decomposition reflect the nature of the binding 
between the metal and ligand atoms and the stability of the complexes. ${ }^{28}$ The later steps appeared to have left the metal ion with oxygen or alone, which reflects the affinity of the metal atoms towards oxygen, according to

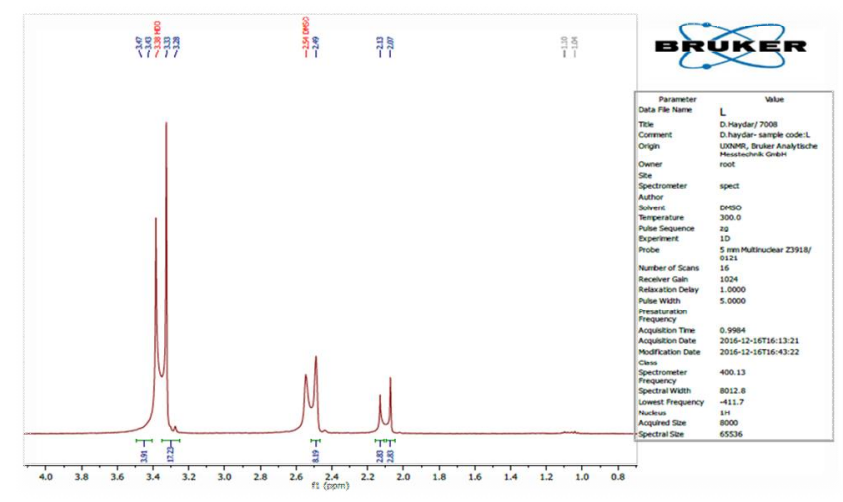

Fig. 7. ${ }^{1} \mathrm{H}$ NMR spectrum for the $\mathrm{H}_{2} \mathrm{~L}$ ligand

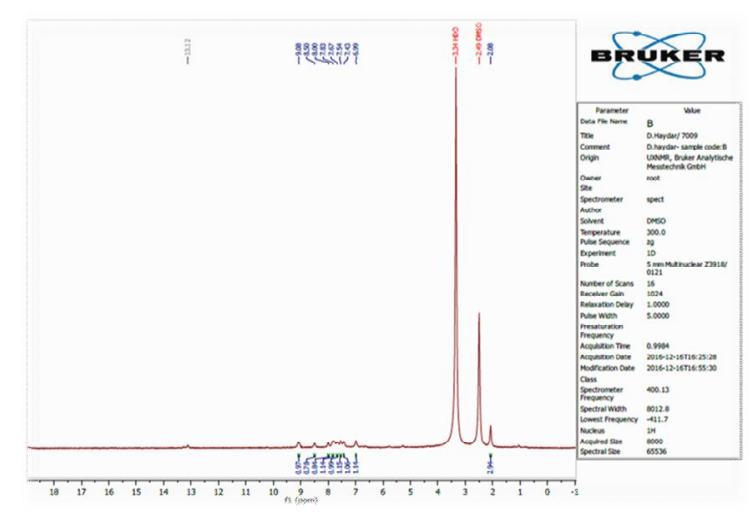

Fig. 9. ${ }^{1} \mathrm{H}$ NMR spectrum for the Fe(II) complex

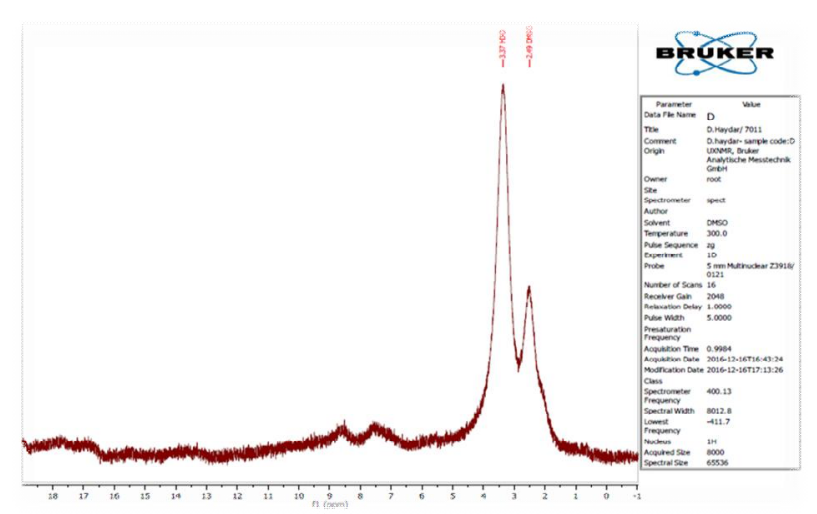

Fig. 11. ${ }^{1} \mathrm{H}$ NMR spectrum for the Ni(II) complex
Pearson's law; ${ }^{29}$ finally, a general trend in the thermolysis steps was observed in the earlier stages, where the small molecules were first to be lost, followed by the larger molecules.

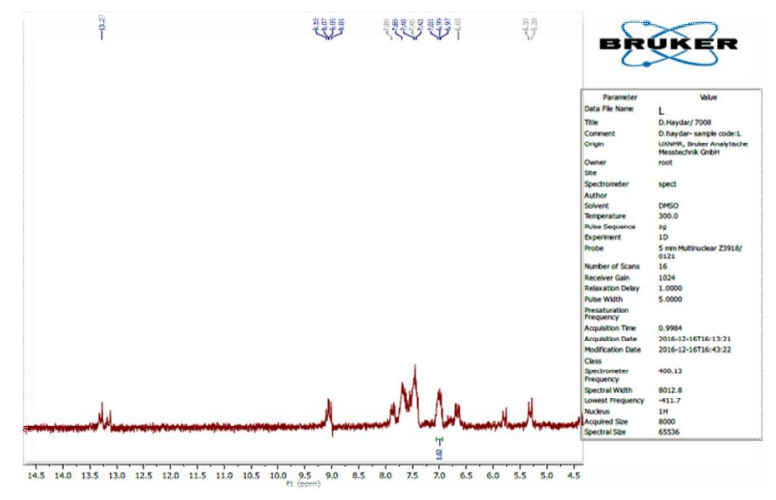

Fig. 8. ${ }^{1} \mathrm{H}$ NMR spectrum (zoom) for the $\mathrm{H}_{2} \mathrm{~L}$ ligand

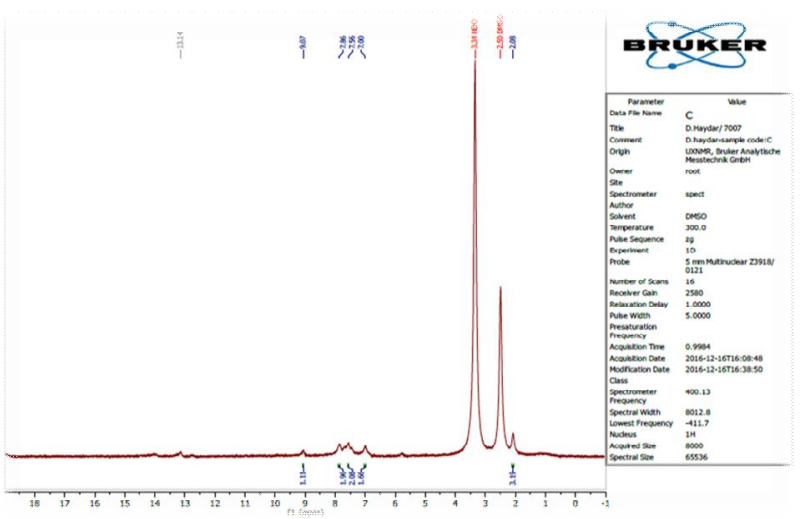

Fig. 10. ${ }^{1} \mathrm{H}$ NMR spectrum for the Co(II) complex

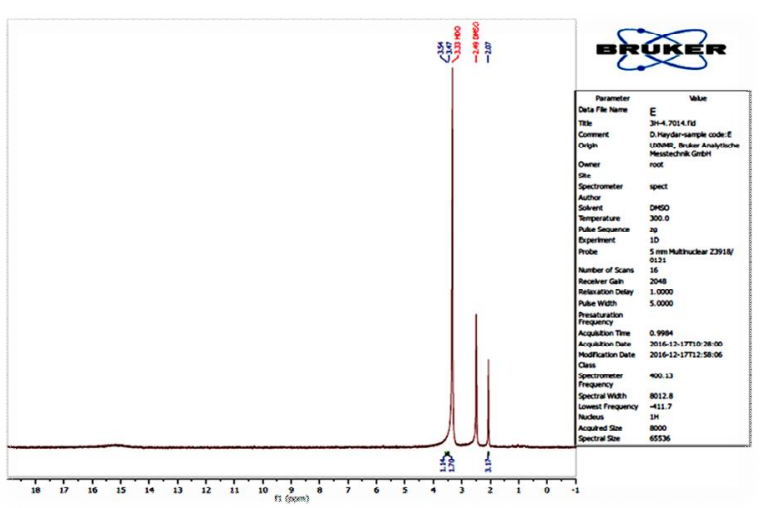

Fig. 12. ${ }^{1} \mathrm{H}$ NMR spectra for the $\mathrm{Cu}$ (II) complex 
Table 3. Thermal decomposition of the $\mathrm{H}_{2} \mathrm{~L}$ ligand and its metal complexes

\begin{tabular}{|c|c|c|c|c|c|c|}
\hline \multirow{2}{*}{ Compound } & \multirow{2}{*}{$\begin{array}{c}\text { Molecular } \\
\text { weight, } \mathrm{g} / \mathrm{mol}\end{array}$} & \multicolumn{2}{|c|}{ Weight loss, \% } & \multirow{2}{*}{ Thermal range, $\mathrm{K}$} & \multirow{2}{*}{ Decomposed compounds } & \multirow{2}{*}{ Produced compounds } \\
\hline & & Found & Calcd. & & & \\
\hline \multirow{2}{*}{$\mathrm{H}_{2} \mathrm{~L}$} & \multirow{2}{*}{392} & 78 & 76.959 & $343-728$ & $2\left(\mathrm{C}_{7} \mathrm{H}_{6} \mathrm{O}\right),\left(\mathrm{C}_{6} \mathrm{H}_{4} \mathrm{~N}\right)$ & $\mathrm{C}_{6} \mathrm{H}_{4} \mathrm{~N}$ \\
\hline & & 24 & 22.959 & $728-973$ & $\downarrow \mathrm{C}_{6} \mathrm{H}_{4} \mathrm{~N}$ & 0 \\
\hline \multirow[b]{3}{*}[\mathrm{Fe}_{2}(\mathrm{H}_{2}\mathrm{L})(\mathrm{L}^{\prime})_{2}]{$\mathrm{Cl}_{2}$} & \multirow[b]{3}{*}{933.45} & 7.35 & 7.60 & $973-633$ & $\downarrow \mathrm{Cl}_{2}$ & $\mathrm{C}_{50} \mathrm{H}_{34} \mathrm{Fe}_{2} \mathrm{~N}_{6} \mathrm{O}_{2}$ \\
\hline & & 19.12 & 19.28 & $633-798$ & $\mathrm{C}_{12} \mathrm{H}_{8} \mathrm{~N}_{2}$ & $\mathrm{C}_{38} \mathrm{H}_{26} \mathrm{Fe}_{2} \mathrm{~N}_{4} \mathrm{O}_{2}$ \\
\hline & & 19.12 & 19.29 & $798-983$ & $\downarrow \quad \mathrm{C}_{12} \mathrm{H}_{8} \mathrm{~N}_{2}$ & $\begin{array}{c}\mathrm{C}_{26} \mathrm{H}_{18} \mathrm{~N}_{2} \mathrm{O} \\
\mathrm{FeO} \\
\mathrm{Fe}\end{array}$ \\
\hline \multirow{3}{*}[\mathrm{Co}_{2}(\mathrm{H}_{2}\mathrm{L})(\mathrm{L}^{\prime})_{2}]{$\mathrm{Cl}_{2}$} & \multirow{3}{*}{939.63} & 7.3 & 7.55 & $303-378$ & $\downarrow \quad \mathrm{Cl}_{2}$ & $\mathrm{C}_{50} \mathrm{H}_{34} \mathrm{Co}_{2} \mathrm{~N}_{6} \mathrm{O}_{2}$ \\
\hline & & 19.09 & 19.16 & $378-563$ & $\downarrow \quad \mathrm{C}_{12} \mathrm{H}_{8} \mathrm{~N}_{2}$ & $\mathrm{C}_{38} \mathrm{H}_{26} \mathrm{Co}_{2} \mathrm{~N}_{4} \mathrm{O}_{2}$ \\
\hline & & 38.18 & 38.36 & 563-878 & $\begin{array}{ll}\downarrow & \mathrm{C}_{24} \mathrm{H}_{16} \mathrm{~N}_{4} \\
\end{array}$ & $\mathrm{C}_{14} \mathrm{H}_{10} \mathrm{Co}_{2} \mathrm{O}_{2}$ \\
\hline \multirow{3}{*}[\mathrm{Ni}_{2}(\mathrm{H}_{2}\mathrm{L})(\mathrm{L}^{\prime})_{2}]{$\mathrm{Cl}_{2}$} & \multirow{3}{*}{939.15} & 7.35 & 7.56 & $373-633$ & $\downarrow \mathrm{Cl}_{2}$ & $\mathrm{C}_{50} \mathrm{H}_{34} \mathrm{Ni}_{2} \mathrm{~N}_{6} \mathrm{O}_{2}$ \\
\hline & & 22.06 & 22.3 & $633-758$ & $\downarrow \quad \mathrm{C}_{14} \mathrm{H}_{10} \mathrm{O}_{2}$ & $\mathrm{C}_{36} \mathrm{H}_{24} \mathrm{Ni}_{2} \mathrm{~N}_{6}$ \\
\hline & & 19.11 & 19.20 & $758-1073$ & $\downarrow \quad \mathrm{C}_{12} \mathrm{H}_{8} \mathrm{~N}_{2}$ & $\begin{array}{c}\mathrm{C}_{24} \mathrm{H}_{16} \mathrm{~N}_{4} \\
2 \mathrm{Ni}\end{array}$ \\
\hline \multirow{4}{*}[\mathrm{Cu}_{2}(\mathrm{H}_{2}\mathrm{L})(\mathrm{L}^{\prime})_{2}]{$\mathrm{Cl}_{2}$} & \multirow{4}{*}{948.07} & 11.11 & 11.28 & $473-603$ & $\downarrow \quad \mathrm{C}_{7} \mathrm{H}_{5} \mathrm{O}$ & $\mathrm{C}_{43} \mathrm{H}_{29} \mathrm{Cl}_{2} \mathrm{~N}_{6} \mathrm{O}, 2 \mathrm{Cu}$ \\
\hline & & 7.9 & 7.5 & $603-671$ & $\downarrow \quad \mathrm{Cl}_{2}$ & $\mathrm{C}_{43} \mathrm{H}_{29} \mathrm{~N}_{6} \mathrm{OCu}, \mathrm{CuO}$ \\
\hline & & 19.07 & 19.01 & $671-803$ & $\downarrow \mathrm{C}_{12} \mathrm{H}_{8} \mathrm{~N}_{2}$ & $\begin{array}{c}\mathrm{C}_{31} \mathrm{H}_{21} \mathrm{~N}_{4}, \mathrm{CuO} \\
\mathrm{Cu}\end{array}$ \\
\hline & & 19.00 & 19 & $803-1008$ & $\downarrow \mathrm{C}_{12} \mathrm{H}_{8} \mathrm{~N}_{2}$ & $\begin{array}{c}\mathrm{C}_{19} \mathrm{H}_{13} \mathrm{~N}_{2}, \mathrm{CuO} \\
\mathrm{Cu}\end{array}$ \\
\hline
\end{tabular}

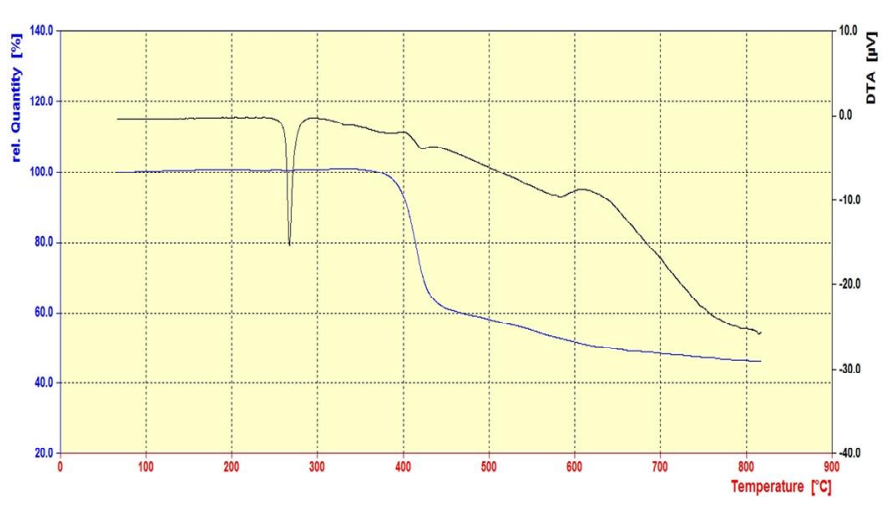

Fig. 13. TGA and DTG thermographs of $\mathrm{H}_{2} \mathrm{~L}$

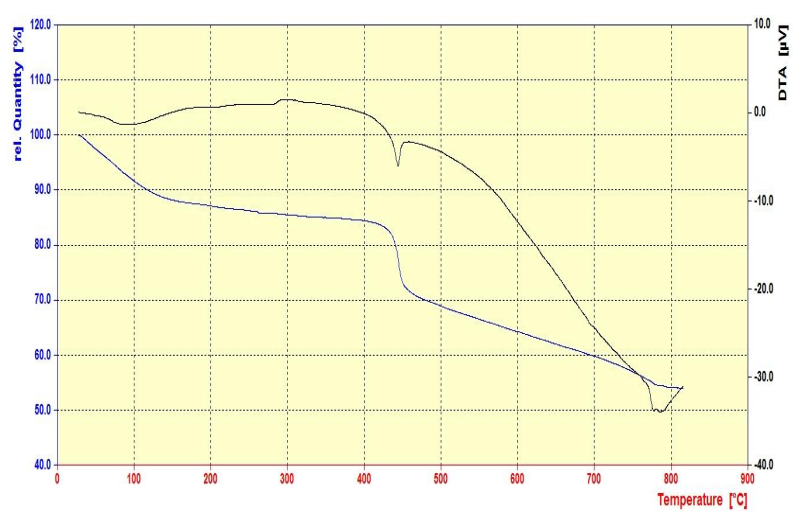

Fig. 15. TGA and DTA thermographs of $\left.\left[\mathrm{Co}_{2}\left(\mathrm{H}_{2} \mathrm{~L}\right)\left(\mathrm{L}^{\prime}\right)_{2}\right] \mathrm{Cl}_{2}\right]$

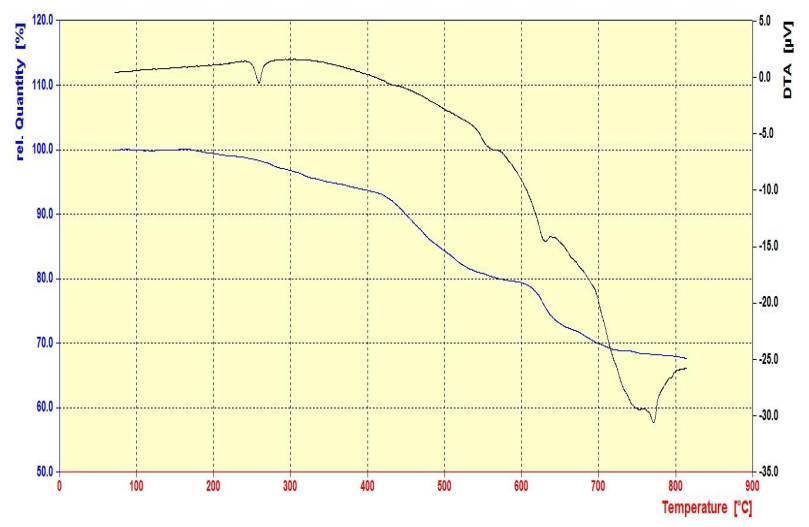

Fig. 14. TGA and DTA thermographs of $\left[\mathrm{Fe}_{2}\left(\mathrm{H}_{2} \mathrm{~L}\right)\left(\mathrm{L}^{\prime}\right)_{2}\right] \mathrm{Cl}_{2}$

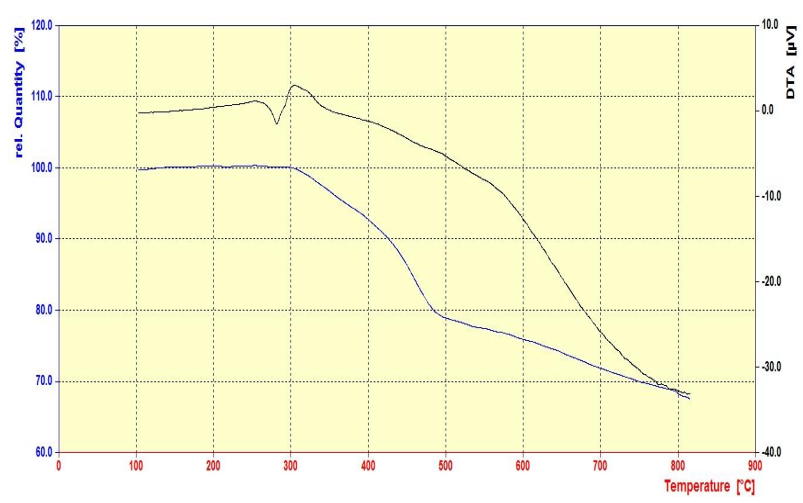

Fig. 16. TGA and DTA thermographs of $\left.\left[\mathrm{Ni}_{2}\left(\mathrm{H}_{2} \mathrm{~L}\right)\left(\mathrm{L}^{\prime}\right)_{2}\right] \mathrm{Cl}_{2}\right]$ 


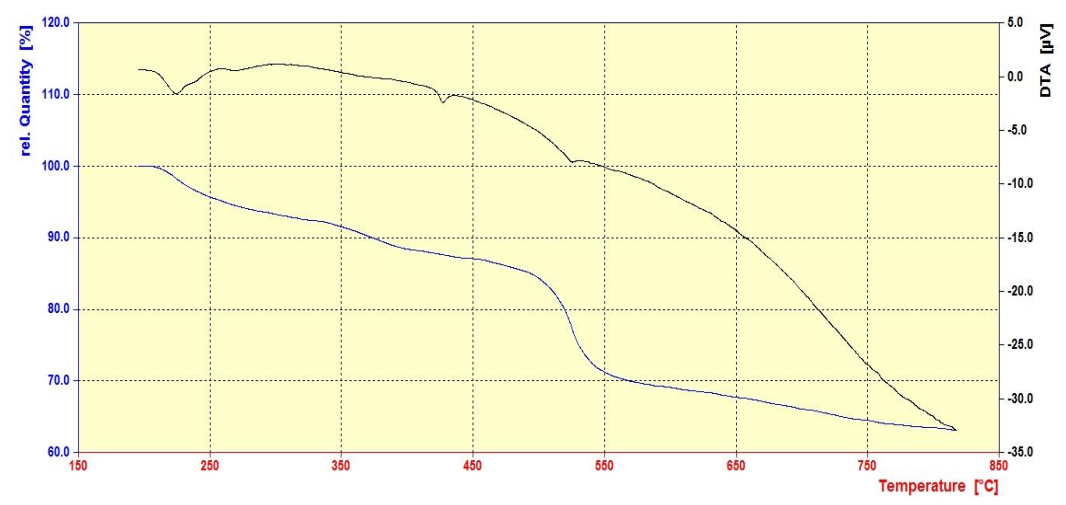

Fig. 17. TGA and DTA thermographs of $\left.\left[\mathrm{Cu}_{2}\left(\mathrm{H}_{2} \mathrm{~L}\right)\left(\mathrm{L}^{\prime}\right)_{2}\right] \mathrm{Cl}_{2}\right]$

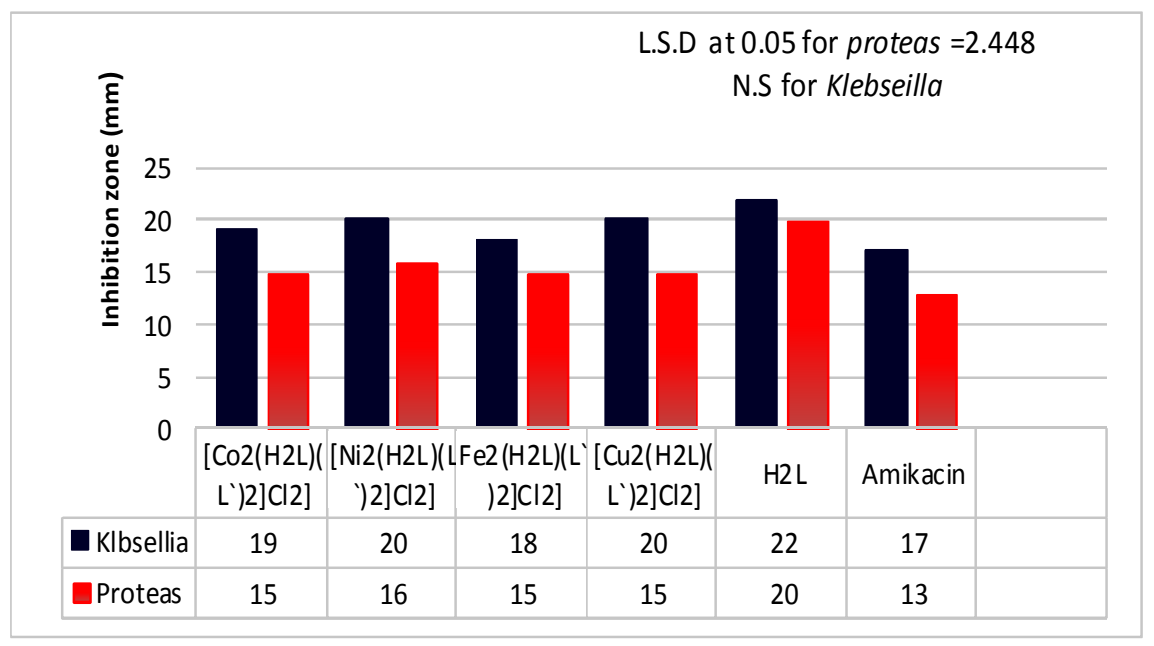

Fig. 18. Inhibition zone ( $\mathrm{mm}$ ) produced due to the prepared compounds against Proteas and Klebseilla

\subsection{Antibacterial Activity}

The primary ligand and its metal complexes were studied against two bacterial species, which were gram positive and gram negative (Kelbsiella and Proteas), as shown in Fig. 18, using diffusion agar plates. The sensitivity of bacteria for these compounds have been studied through inhibition zone diameters around the wells. The ligand $\left(\mathrm{H}_{2} \mathrm{~L}\right)$ was more highly effective against both Kelbsiella and Protea than the complexes. Klebsiella has a higher sensitivity for these complexes than the Proteas bacteria. All of the ligands and their complexes showed more significant effects against Kelbsiella and Protea than the antibiotic (Amikacin). Many metal complexes are essential to living bacteria as structural proteins and using in oxidation-reduction processes but a high concentration of these elements has an inhibitory effect, which is mainly due to altering the conformational structures of proteins, and affecting the nucleic acid and plasma membranes integrity. The toxicity of these complexes included reactive oxygen species (ROS), reduced enzyme and non-enzyme antioxidant, deactivation of enzymes, damage to the plasma membrane and restricted electron transport. ${ }^{30}$

\section{Conclusions}

Metal ion complexes of $\mathrm{Co}(\mathrm{II}), \mathrm{Ni}(\mathrm{II}), \mathrm{Cu}(\mathrm{II})$ and $\mathrm{Fe}$ (II) for the mixed ligands (imine of benzidine $\left(\mathrm{H}_{2} \mathrm{~L}\right)$ and 1,10-phenanthroline (L')) were synthesized and characterized. Through the measurements of the electrical conductivity of the complexes, it was found that all of them conducted in a 1:2 ratio. FT-IR measurements elucidated the fact that the Schiff base ligand $\left(\mathrm{H}_{2} \mathrm{~L}\right)$ coordinated with metal ions as a bidentate ligand via its nitrogen and oxygen atoms, and that 1,10-phenanthroline coordinated by the two nitrogen atoms. According to physical measurements and the magnetic moments determined, it was clear that most of complexes had 
tetrahedral geometries, with the exception of the $\mathrm{Cu}(\mathrm{II})$ complex which had a square planar geometry. Thermogravimetric analysis indicated that the chlorine in most complexes that was not directly coordinated to the metal ions was lost at lower temperatures, and the latest steps appeared to have left the metal ion with oxygen or alone, which reflects the affinity of the metal atoms for oxygen. The antimicrobial activity of the complexes indicates that the ligand $\left(\mathrm{H}_{2} \mathrm{~L}\right)$ was more effective against both Kelbsiella and Protea than the complexes as determined from their growth and sensitivity.

\section{Acknowledgments}

We would like to thank Department of Chemistry, College of Science, Kerbala University, for financial support.

\section{References}

[1] Yousif, E.; Majeed, A.; Al-Sammarrae, K.; Salih N.; Salimon J.; Abdullah B. Metal Complexes of Schiff base: Preparation, Characterization and Antibacterial Activity. Arab. J. Chem. 2017, 10, 1639-1644. https://doi.org/10.1016/j.arabjc.2013.06.006 [2] Ejidike, I.; Ajibade, P. Ruthenium(III) Complexes of Heterocyclic Tridentate (ONN) Schiff Base: Synthesis, Characterization and its Biological Properties as an Antiradical and Antiproliferative Agent. Int. J. Mol. Sci. 2016, 17, 60. https://doi.org/10.3390/ijms17010060

[3] Murtaza, S.; Akhtar, M.; Kanwal, F.; Abbas, A.; Ashiq, S.; Shamim S. Synthesis and Biological Evaluation of Schiff Bases of 4-Aminophenazone as an Anti-inflammatory, Analgesic and Antipyretic Agent. J. Saudi Chem. Soc. 2017, 21, 359-372. https://doi.org/10.1016/j.jscs.2014.04.003

[4] Divya, K.; Pinto, G.; Pinto, A. Application of Metal Complexes of Schiff Bases as an Antimicrobial Drug: A Review of Recent Works. Int. J. Curr. Pharm. Res. 2017, 9, 27-30.

https://doi.org/10.22159/ijcpr.2017.v9i3.19966

[5] Anacona, J.; Mago, K.; Camus, J. Antibacterial Activity of Transition Metal Complexes with a Tridentate NNO Amoxicillin Derived Schiff Base. Synthesis and Characterization. Appl. Organomet. Chem. 2018, 32, 1. https://doi.org/10.1002/aoc.4374 [6] Barnabas, M.; Parambadath, S.; Nagappan, S.; Ha, C. Sulfamerazine Schiff-Base Complex Intercalated Layered Double Hydroxide: Synthesis, Characterization, and Antimicrobial Activity. Heliyon. 2019, 5, e01521.

https://doi.org/10.1016/j.heliyon.2019.e01521

[7] Sunday Nworie, F. Bis(Salicylidene) Ethylenediamine(salen) and bis(Salicylidene) Ethylenediamine-Metal Complexes: from Structure to Biological Activity. J. Anal. Pharm. Res. 2016, 3, 1. https://doi.org/10.15406/japlr.2016.03.00076

[8] Akhter, S.; Zaman, H.; Mir, S. Dar, A.M. Synthesis of Schiff Base Metal Complexes: A Concise Review. Eur. Chem. Bull. 2017, 6, 475-483. https://doi.org/10.17628/ecb.2017.6.475-483

[9] Rao, N.; Mishra, D.; Maurya, R. Synthesis and Characterisation of Some Novel CIS-Dioxo-Molybdenum(VI) Complexes of Schiff Bases Derived from Salicylaldehyde. Synth. React. Inorg. Met. Chem. 1995, 25, 437-449.

https://doi.org/10.1080/15533179508218232
[10] Felthouse, T.; Hendrickson, D. Magnetic Exchange Interactions in Binuclear Transition-Metal Complexes. 17. Benzidine and pPhenylenediamine, Extended Aromatic Diamine Bridging Ligands in Binuclear Copper(II) 2,2',2"-triaminotriethylamine and Vanadyl Bis(hexafluoroacetylacetonate) Complexes. Inorg. Chem. 1978, 17, 2636-2648. https://doi.org/10.1021/ic50187a054

[11] El-Tabl, A. Synthesis and Physico-Chemical Studies on Cobalt(II), Nickel(II) and Copper(II) Complexes of Benzidine Diacetyloxime Transit. Met. Chem. 2002, 27, 166-170. https://doi.org/10.1023/A:1013952726823

[12] Zhao, P.; Zhai, S.; Dong, J.: Gao, L.; Liu X.; Wang L.; Kong J.; Li L. Synthesis, Structure, DNA Interaction, and SOD Activity of Three Nickel(II) Complexes Containing L-Phenylalanine Schiff Base and 1,10-Phenanthroline. Bioinorg. Chem. Appl. 2018, 2018, 8478152. https://doi.org/10.1155/2018/8478152

[13] Patel, R. N.; Singh, N. G.; Gundla, V.L.N. Synthesis, Structure and Properties of Ternary Copper(II) Complexes of ONO Donor Schiff Base, Imidazole, 2,2'-Bipyridine and 1,10-Phenanthroline. Polyhedron 2006, 25, 3312-3318. https://doi.org/10.1016/j.poly.2006.06.017

[14] Kosolapov, D.; Kuschak, P.; Vainshtein, M.; Vatsourina, A.V.; Weißner, A.; Kästner, M.; Müller, R.A. Microbial Processes of Heavy Metal Removal from Carbon-Deficient Effluents in Constructed Wetlands. Eng. Life Sci. 2004, 4, 403-411. https://doi.org/10.1002/elsc.200420048

[15] Selvamohan, T.; Sandhya, V. Studies on Bactericidal Activity of Different Soaps Against Bacterial Strains J. Microbiol.

Biotechnol. Res. 2012, 2, 646-650.

[16] Bauer, A.W.; Kirby, W.M.M.; Sherris, J.C.; Turck, M. Antibiotic Susceptibility Testing by a Standardized Single Disk Method: Am. J. Clin. Pathol. 1966, 45, 493-496.

https://doi.org/10.1093/ajcp/45.4_ts.493

[17] More, G.; Raut, D.; Aruna, K.; Bootwala, S. Synthesis, Spectroscopic Characterization and Antimicrobial Activity Evaluation of New Tridentate Schiff Bases and their Co(II) Complexes. J. Saudi Chem. Soc. 2017, 21, 954-964.

https://doi.org/10.1016/j.jscs.2017.05.002

[18] Singh, D.K.; Singh, N.; Singh, R. Transethmoidal Meningocele: an Unusual Complication of Intracranial Neoplasm. Int. J. Inorg. Chem. 2013, 2013, 1. https://doi.org/10.1136/bcr-2013-009200

[19] Krishnaveni, G.; Mubarak, M.S; Kiruthika, M.; Elayaperumal, R. Synthesis, Spectral Characterization, Electrochemical Behaviour, In vitro Antimicrobial and DPPH Radical Scavenging Activities of Iron (II), Cobalt (II) Complexes with Imidazolyl Terpyridine. Der Chem. Sin. [Online] 2017, 8.

https://www.imedpub.com/articles/synthesis-spectralcharacterization-electrochemical-behaviour-in-vitroantimicrobialand-dpph-radical-scavenging-activities-of-iron.php?aid=18214 (accessed Oct 06, 2021).

[20] Larsen, C.; Wenger, O. Photoredox Catalysis with Metal Complexes Made from Earth-Abundant Elements. Chem A Eur J., 2018, 24, 2039-2058. https://doi.org/10.1002/chem.201703602 [21] San Tan, S.; Yanagisawa, S.; Inagaki, K.; Kassim, M.B.; Morikawa, Y. Experimental and Computational Studies on Ruthenium(ii) bis-Diimine Complexes of $\mathrm{N}, \mathrm{N}^{\prime}$-chelate Ligands: the Origin of Changes in Absorption Spectra Upon Oxidation and Reduction. Phys. Chem. Chem. Phys. 2019, 21, 7973. https://doi.org/10.1039/C8CP05016C

[22] Goodgame, D.M.L.; Goodgame, M.; Cotton, F.A. Electronic Spectra of Some Tetrahedral Nickel(II) Complexes. J. Am. Chem. Soc., 1961, 83, 4161-4167. https://doi.org/10.1021/ja01481a014 [23] Lever, A. Inorganic Electronic Spectroscopy, 2nd ed.; Elsevier Pub. Co: Amsterdam, New York, 1968. 
[24] Mihsen, H.H.; Shareef N.D. Synthesis, Characterization of Mixed-Ligand Complexes Containing 2,2-Bipyridine and 3Aminopropyltriethoxysilane. J. Phys. Conf. Ser. 2018, 1032, 1. https://doi.org/10.1088/1742-6596/1032/1/012066

[25] Venanzi, L.M. Tetrahedral Complexes of Nickel (II) and the Factors Determining their Formation. J. Inorg. Nucl. Chem. 1958 , 8(C), 137-142. https://doi.org/10.1016/0022-1902(58)80175-X [26] Knittl, E.T.; Abou-Hussein, A.A.; Linert, W. Syntheses, Characterization, and Biological Activity of Novel Mono- and Binuclear Transition Metal Complexes with a Hydrazone Schiff Base Derived from a Coumarin Derivative and Oxalyldihydrazine. Monatshefte für Chemie-Chemical Mon. 2018, 149, 431-443. https://doi.org/10.1007/s00706-017-2075-9

[27] Mihsen, H.H.; Abass, S.K.; Abass, A.K.; Hussain, K.A.; Abbas, Z.F. Template Synthesis of Sn(II), Sn(IV) and Co(II) Complexes via 3Aminopropyltriethoxysilane and Salicylaldehyde and Evaluate their Antibacterial Sensitivity. Asian J. Chem. 2018, 30, 2277-2280. https://doi.org/10.14233/ajchem.2018.21439

[28] Czakis-Sulikowska, D.; Malinowska, A.; Radwañska-Doczekalska, J. Synthesis, Properties and Thermal Decomposition of BipyridineOxalato Complexes with $\mathrm{Mn}$ (II), $\mathrm{Co}(\mathrm{II}), \mathrm{Ni}$ (II) and $\mathrm{Cu}(\mathrm{II})$. Pol. J. Chem. 2000, 74, 607-614.

[29] Pearson, R.G. Hard and Soft Acids and Bases. J. Am. Chem. Soc. 1963, 85, 3533-3539. https://doi.org/10.1021/ja00905a001

[30] Sundaram, S.; Kanniappan, G.V.; Kannappan, P. Enzymatic and Non Enzymatic Antioxidant Activity of Tabernaemontana divaricate R.Br. against DEN and Fe-NTA Induced Renal Damage in Wistar Albino Rats. J. Appl. Pharm. Sci. 2015, 5, 33-37. https://doi.org/10.7324/JAPS.2015.50506

Received: September 27, 2019 /Revised: October 11, 2019 / Accepted: October 17, 2019

\section{СИНТЕЗ, ХАРАКТЕРИСТИКА \\ І БІОЛОГІЧНА АКТИВНІСТЬ \\ СУМІШІ ЛІГАНДІВ (ІМІНУ БЕНЗИДИНУ \\ ТА 1,10-ФЕНАНТРОЛІНУ) ТА ЙОНІВ Fе(II), Co(II), Ni(II) TA Cu(II)}

Анотація. За реакиією первинного ліганду (іміну бензидину) ( $\left.\mathrm{H}_{2} L\right)$ та вторинного ліганду (1,10-фенантролін) (L) з йонами металів $\mathrm{Fe}(\mathrm{II}), \mathrm{Co}(\mathrm{II}), \mathrm{Ni}(\mathrm{II})$ ma Cu(II) у мольному співвідношенні 1:2:2 синтезовані бінуклеарні металічні комплекси. За допомогою елементарного аналізу, FT-IR, UV-VIS, магнітної сприйнятливості, молярної провідності, ${ }^{1}$ Н ЯМР та термогравіметричного аналізу TGA-DTA визначено характеристику комплексів. Показано, щуо комплекси з $\mathrm{Fe}(\mathrm{II}), \mathrm{Co}(\mathrm{II}) \mathrm{i}$ $\mathrm{Ni}(\mathrm{II})$ мають восьмигранну геометрію, тоді як комплекс 3 Си(II) має квадратну площинну геометрію. Всі синтезовані комплекси стійкі і можуть зберігатися місяиями без суттєвих змін. 3 використанням дифузійних агарових пластинок проведено оиінку антибактеріальної активності одержсаних сполук стосовно двох видів бактерій, грампозитивної та грамнегативної (Kelbsiella та Proteus). Встановлено, що бактерія Klebsiella є більш чутливою до циих сполук, ніж Proteus. Показано, шөо синтезовані сполуки мають більший вплив на бактерії у порівнянні з антибіотиком (Амікацин).

Ключові слова: основа Шиффа, бінуклеарні металічні комплекси, 1,10-фенантролін, термогравіметричний аналіз, біологічна активність. 